\title{
Russian in Estonia's public sector: 'Playing on the borderline' between official policy and real-life needs
}

\author{
Maimu Berezkina \\ MultiLing, University of Oslo, Norway
}

\begin{abstract}
This article examines the use of Russian in state communication in officially monolingual Estonia. Drawing on interviews with high-level public employees in four central state institutions and an analysis of these institutions' websites, the article shows that while Russian is not specifically mentioned in the laws, it is de facto widely present in the virtual and physical public sector of Estonia. Russian is an important linguistic resource for employees in positions that involve contact with the public in the capital Tallinn, and state institutions also invest in Russian by translating their websites. The study reveals a covert policy of accommodating Russian speakers despite the erasure of Russian in Estonia's overt language policy. Furthermore, it highlights how investigating covert policies discloses a growing commodification of Russian in the public sector in terms of valuing linguistic skills in the language.
\end{abstract}

Keywords: Russian; Estonia; language policy; commodification; public sector

\section{Introduction}

Social, cultural and economic integration of the Russian-speaking population has been one of the most important challenges of language planning and national policy in Estonia since the restoration of independence in 1991 (Lauristin and Heidmets 2002; Kivirähk 2014). Today, more than two decades later, linguistic and ideological tensions between Estonian and Russian speakers continue to exist. This situation is intensified by official legislation codifying Estonia as a monolingual state. When investigating language policy and ideology, however, it is not sufficient to draw conclusions based only on declared policy statements, which can be seen as manifestations of 'wishes of groups in authority' (Shohamy 2006, 3). Alongside official regulations, the specific implementations of policy in practice, and real-life language use are also central considerations for understanding linguistic ideologies and 
practices in a society (Spolsky 2004). In other words, it is important to look at both the 'macro' and 'micro' domains of language policy, which stand in a complex dialectical relationship (Nekvapil 2006). Schiffman $(1995,13)$ sees language policy as dichotomized into overt (explicit, formalized) and covert (implicit, informal) aspects. Following Schiffman's position, this article aims to show that in Estonian state institutions, a much more 'Russianfriendly' covert policy exists in parallel to the overt monolingual ideology. This allows for extensive state communication in Russian, despite the official policy. The need to foster this type of communication in the service oriented sectors, and in the public sector in particular, increases the value of Russian, contributing to its commodification in the society and making it an attractive asset on the job market.

Commodification of language has become an important theme in sociolinguistics (see Heller 2010 for an overview), as our ideas about language are increasingly being recast in economic terms. In the new global economy where markets expand well beyond the boundaries of nation-states, communication skills and exchange of information are crucial for well-functioning social and commercial relations. Language and communication skills, or 'wordforce' (Duchêne and Heller 2012), are hence regarded as an important asset in various workplaces in this increasingly service-based and technologically advanced economy. Some of the areas for investigating the role of language in economy have until today been the tourism sector, call centers, language teaching and marketing (Heller 2010). In this article, I examine linguistic commodification in a different setting, namely in public sector workplaces, looking at four state institutions: Tax and Customs Board, Police and Border Guard Board, Social Insurance Board and Unemployment Insurance Fund. It is important to emphasize that I follow a broader understanding of 'language commodification', namely the process of assigning economic value to language, and changing the relative positioning of a language in the local, in this case national, political economy of language (Gal 1989). The commodification of Russian is reflected in a valuing of Russian as 'a resource' (Ruíz 1984) in the public sector of Estonia. My data show how Estonian state institutions, rather than strictly following overt language laws, to a large degree base their covert language policy on the pragmatic value of the various languages in communication with the public. Since communication is central for service provision in state institutions, they are faced with the need to employ people with at least bilingual language skills (Estonian and Russian) who would be able to interact also with the part of the population that has an insufficient knowledge of Estonian. As a result, the communication sector of Estonian state institutions becomes an arena for language commodification in connection to the increased employment 
chances associated with the knowledge of Russian. Together with the importance of Russian in the Estonian tourism industry and for economic relations across the post-Soviet space, the valorization of Russian in public sector workplaces adds to an enhanced value of the Russian language on the linguistic market (Bourdieu 1991) in Estonia.

In my analysis I rely mainly on interview data with key actors at the four institutions. With these interviews as a point of departure, I will discuss how state employees in Estonia perceive the role of Russian in their interactional practices and how this is reflected in language use both in the physical and virtual public sector. I will first give a brief account of the history and current status of the Russian-speaking population in Estonia. I will continue by describing the provisions that exist in the legislation of officially monolingual Estonia for the inclusion of different linguistic groups into state communication. I will then move on to specific state institutions and look at how these laws are followed and appropriated in practice, and more specifically, what value is being attached to the employees' language skills in the linguistically heterogeneous capital Tallinn. This will be followed by a discussion of market value attached to different languages in Estonia. Finally, I will examine the way state institutions in Estonia are investing into translations of their websites and web platforms into Russian alongside with English. Official state communication in the virtual public space is an important perspective to consider in the case of the so-called 'e-Estonia', where a major part of the communication between the state and the public takes place online.

\section{Russian in Estonia's public space: historical background and current situation}

Before the Second World War and the Soviet annexation in 1940, Estonia was linguistically relatively homogenous. According to the 1934 census, Estonians composed $88.1 \%$ of the population, followed by Russians (8.2\%), Germans (1.5\%), Swedes (0.7\%), Latvians (0.5\%), and Jews (0.4\%). By 1989, only $61.5 \%$ of the population remained Estonian-speaking, while $35.2 \%$ of the country's population was Russian-speaking (mostly Russians, Belarusians and Ukrainians) (Eesti Entsüklopeedia 2012). One of the main reasons for this dramatic change alongside deportations, executions and the fleeing to the West that took place during and shortly after the war (accounting for a total loss of $25 \%$ of the pre-World War Two population), was the industrialization campaign of the 1960s and 1970s. This entailed a large inflow of mainly Russian-speaking workers from other parts of the USSR, who mostly settled in the northeastern part of the country and in Tallinn. The new linguistic composition of 


\section{DRAFT - Please do not cite}

Estonia created 'favorable conditions for territorial and functional language shifts from Estonian to Russian' (Rannut 2008, 425). Russian was the lingua franca of the USSR and the language of its unified linguistic market (Bourdieu 1991). It became the language of everyday public communication between different language communities and the second official language on the territory of Estonia, even completely dominating some areas of the public and economic life (for example, railways, banking, mining and the militia) (Rannut 2008). A situation of asymmetrical bilingualism arose: knowledge of Estonian was not considered necessary for non-Estonians, whereas Estonians were required to know Russian in order to participate in the labor market. It was under the conditions of perestroika that a change in official policy was offered, confronting the growth of Russian monolingualism and domain loss for Estonian. Importantly, this policy was implemented through the 1989 Language Act, which was guided by the principle of bilingualism in services and state agencies (Rannut 2008, 426-427).

After the fall of the Soviet regime in 1991, 'the nation building in the successor states took a turn from official bilingualism to monolingualism' (Pavlenko 2013, 266) but differed substantially across cases. Importantly, Estonia and Latvia were the only successor states that did not offer automatic citizenship to the whole population. Soviet period settlers and their descendants had to apply for naturalization, which included passing a language test, as well as a test on history and civics (Pavlenko 2008, 287). This was accompanied by a process of linguistic derussification, with Russian being deliberately removed from the public space. Such erasure (Irvine and Gal 2000) of Russian can be seen as a way of re-defining Estonia's boundaries and demarcating the country away from the Soviet space. In order to restore all functions of the titular language, Estonia chose to exercise control-oriented and explicit language policies stated out in numerous laws and regulations, and created special agencies in order to carry out the regulating functions (Siiner 2006). Established political and economic power relations were broken by the shift from socialist economic order to capitalism, which among other things brought about new linguistic priorities, positioning English above Russian on the linguistic market. The status of Russian was heavily downgraded and the previously majority language was removed from official paperwork and communication, as well as from state-sponsored media, and public signage (Pavlenko 2008, 282). The Language Act from 1995 delegalized Russian as an official means of communication and established professional linguistic requirements of Estonian. Having access to 'social space that functions in one's mother tongue is a valuable asset that gives speakers a certain "guaranteed" social capital compared to those to whom the national language is not their native language' (Siiner and 


\section{DRAFT - Please do not cite}

Vihalemm 2011, 116), and the Russian-speaking population had suddenly lost this 'guaranteed' position. Some Russian speakers in Estonia experienced the shift to an officially Estonian-only society as discrimination, as they had become accustomed to positioning the territory as part of the Soviet Union where they had full rights to use Russian in all areas of public life (Skerrett 2011).

Today, 98\% of Estonia's total population of 1.3 million have either Estonian or Russian as their first language. L1 Russian speakers constitute $29.6 \%$ of the population. $6.95 \%$ of them are citizens of the Russian Federation while further $6.5 \%$ are stateless (Statistics Estonia 2012, based on the census from 2011). These are mostly older people who have no knowledge of Estonian and therefore are unable to pass the language test needed for acquiring Estonian citizenship. It is important to keep in mind that the Russian speakers do not form a single category with a uniform value system and display various levels of integration (Ehala and Zabrodskaja 2014). According to a study by Marju Lauristin (2011), the Russianspeaking population of Estonia can roughly be split into two parts: a successfully integrated group, and a group which is less successfully integrated or not integrated at all. Lauristin makes a further division among the Russian speakers that are not well integrated into the Estonian society: (1) 'Little integrated' (29\% of the Russian speakers), consisting mainly of blue-collar workers, retirees and the unemployed, who have poor Estonian language skills, are mostly stateless and represent all age groups; and (2) 'Unintegrated passive' (22\% of the Russian speakers), which is a group composed of mainly older people, most of whom have a Russian citizenship and a weak civic identity, and who cannot speak Estonian.

More than $60 \%$ of L1 Russian speakers live in and around the capital Tallinn, and almost $30 \%$ reside in the county of Ida-Virumaa in the northeastern part of Estonia (Rannut 2008, 429). Tallinn could be considered a bilingual city in the sense that both Estonian and Russian are first languages of sizeable parts of the population, as $53.2 \%$ of the inhabitants speak Estonian and 43.3\% Russian as their first language (Tallinn City Government 2014). The Russian-speaking population in Estonia is not officially recognized as a minority and is therefore not protected by the European Framework Convention for the Protection of National Minorities or the European Charter for Regional or Minority Languages. The vast majority of public arenas in Estonia, such as administration, public signage, the government, the media and parts of the educational system, continue stressing strong monolingual norms, which keeps creating confrontation between Estonian and Russian speakers. For example, there is an ongoing heated debate on whether Russian-speaking schools should have the right to continue using Russian as the language of instruction in Estonia. Estonia has received criticism from 
both Russia defending the rights of Russian speakers in the Baltic States, as well as from Western European organizations. As Ozolins (2003) outlines, a number of these Western organizations have defined the situation as discrimination of a linguistic minority and have accused the country of undemocratic language policies. More specifically, such policies have been criticized as assimilationist, especially after 2004 when Estonia became a member of the European Union, where norms supporting multiculturalism and the preservation of minority languages and cultural identities prevail (Brubaker 2011).

The official language policy in Estonia privileges the titular language and makes little reference to Russian, which is deemed to be foreign language. Estonia's Language Act from 2011 has a monolingual focus, and this extends also to the language of public administration. The prescribed monolingualism in official communication between the state and the people is clearly stated in the Language Act: 'The language of public administration in state agencies and local government authorities is Estonian’ (2011: §10(1); official translation). According to $\S 12$, if an application is submitted to a state agency in a foreign language, the agency shall respond to it in Estonian and has the right to require a translation into Estonian from the person who submits it. However, it is also stated that a foreign language may be used both in oral and written communication with officials or employees of state agencies by mutual agreement of the parties.

In connection with the position of L1 Russian speakers in present-day Estonia and as a contrast to the monolingually focused Language Act, it is important to mention the Strategy of Integration and Social Cohesion in Estonia 2020 (Lõimuv Eesti 2020), which has as its main objective 'to create a socially cohesive Estonian society in which people with different linguistic and cultural backgrounds actively participate in the social life and share democratic values' (Ministry of Culture 2014, 2). The development plan for this strategy accentuated the need to create a shared information space for all residents, and to support and translate various Russian language media channels (as well as those in English for the new immigrants who do not speak Russian) in order to communicate everyday practical information. Among such channels are the web portals that focus on legislation, everyday life, health, security and matters of the civil society, which sections below will deal with.

\section{Data and method}




\section{DRAFT - Please do not cite}

In the following, I will mostly be drawing on interview data collected at four state institutions during fieldwork in Tallinn in June and August 2014, namely the Tax and Customs Board, Police and Border Guard Board, Social Insurance Board and Unemployment Insurance Fund. These institutions were explicitly chosen for the reason that they are central for the meeting between the authorities and the public, since most of the grown-up population at some point in their life need to be in contact with them. It is also important to keep in mind that as representatives of the state, these institutions implement the official language laws initiated by the state. The article analyses the perspective of powerful agents whose decisions have a direct impact on language policy in Estonian state institutions, as they create and manage the communication strategies of these institutions.

Altogether five in-depth semi-structured interviews were conducted with seven people: a joint interview with two employees at the Tax and Customs Board, two separate interviews at the Police and Border Guard Board, one interview at the Social Insurance Board and a joint interview with two respondents working at the Unemployment Insurance Fund. The following topics formed the basis for the interviews: (1) the use of different languages in oral communication (by employees in the service centers and call centers); (2) translation of written texts in the service centers (signage, brochures, etc.) and on their website; (3) the importance of online communication with the public. All the interviews were conducted in Estonian, and the excerpts used in this article were translated by the present author. The interviewees were specifically chosen because of their potential for a powerful influence on the language policy at their institution, as they were directly responsible for communication strategies at the service centers and/or online. Central to this study is the respondents' negotiation between, on the one hand, the interpretation and appropriation at the institutional level of the macro-level state language policy texts, and on the other, the explicit need for Russian both at the service centers in Tallinn and in online state communication. The interviews give an insight into the institutional discourses (Sarangi and Roberts 1999) at Estonian state institutions by illustrating how language policy makers at these institutions explain the reasons behind the use of specific languages in their communication strategies.

In addition to the interview data, this article is based on an analysis of the state institutions' websites. Hine (2000) differentiates between two types of online contexts: the Web as an interactive space (the dialogic Web), and the Web as a repository of texts (the monologic Web). The websites of Estonian state institutions belong mostly to the latter type, which according to Kelly-Holmes $(2015,132)$, allows for the examination of 'top-down language policies and the extent to which offline national official and de jure policies are 
respected in cyberspace'. In the analysis of the websites I employed the method of 'virtual linguistic ethnography' (Kelly-Holmes 2015). I first identified the available language options and then used quantitative and qualitative approaches to investigate the amount, relevance and currency of the information offered in various languages. When investigating a website it is important for the researcher to be flexible and to follow intertextual and hypertextual links, as this makes it possible to capture linguistic trajectories from and to the website (ibid.). In order to set limits to the otherwise very large number of sub-pages to be investigated, this was done on two levels of the websites' architecture: (1) the front page; (2) the subpages which were referred to through hyperlinks in the front page menu.

\section{Russian as a linguistic resource at state service centers and on the Estonian job market}

For institutions of the Estonian nation-state, Russian can be seen as a challenge. On the one hand, they are expected to follow the official regulations heavily prioritizing the titular language. On the other hand, these institutions have as their goal to provide social services to the whole population, which includes providing services and disseminating information in such a way that will reach the whole target group, irrespective of the individuals' linguistic background. A similar dilemma connected to the use of Russian was reported in all the interviews. According to my informants, employees at the service centers of state institutions in Tallinn are typically able to communicate with the clients in both Estonian and Russian. In fact, for positions requiring contact with the public, they claim that Russian language proficiency is a salient consideration in recruitment processes to the service jobs. Knowledge of English is considered important as well, but to a smaller degree. All the four institutions in question are mainly dealing with residents of Estonia and are therefore much more in contact with people with Estonian or Russian linguistic background, rather than with those who would prefer to communicate with the authorities in English. Such language requirements reflect the real-life situation whereby a part of the population is not able to communicate with the authorities in Estonian, consequently leading to a mismatch between overt and covert language policy. What this means for the Estonian-speaking potential job candidates in Tallinn is that it is profitable for them to invest in Russian skills, as this can become a major asset in getting a job which requires contact with the general public. Based on the interviews, it is possible to conclude that an applicant for such a job is expected to have acquired Russian 


\section{DRAFT - Please do not cite}

skills beforehand. This is how my informant in the Social Insurance Board explained the institution's wish for their employees to be able to communicate in Russian:

We see indeed that in all our activities, Russian constitutes quite a big part and people must have a possibility to contact us in Russian in order to understand what kind of compensation they are entitled to. They have paid social security taxes, they have the right to receive compensation, and consequently they have the right to receive information [...]. This can also be seen from our website, that we should have Russian to the same extent as Estonian.

The Unemployment Insurance Fund offers additional internal training with a specially designed Russian textbook for those employees who still lack the knowledge of some official terminology in Russian (no such training exists for English). This is a practice that has gradually developed based on the institution's experience with the clientele: from the 33,000 registered unemployed in Estonia in the spring of 2014, 32.6\% had no or highly limited Estonian skills. The situation is the same for $35 \%$ of the unemployed in Tallinn (interview data). This makes it crucial to offer both verbal help and translation of information into Russian:

Our goal is to help people get a job, and the best way to help people get a job is when they know and receive all the information in their mother tongue. This is considerably more convenient than doing it in another language or hiring an interpreter between us. We are not pursuing language politics here, we proceed from our goal and it's efficient to provide people with information in their mother tongue.

Similar practices seem to be typical for all the state institutions under investigation. Official regulations such as the Language Act are not being directly violated (see an explanation of $\S 12$ of the Language Act above), but such regulations are certainly not the only factor informing communication strategies. As pointed out by Blommaert et al. (2009), it is important to consider the polycentric environment where language policy is created and negotiated. The various actors who have direct influence on the language policy of the institutions described above need to negotiate and balance different policy priorities against each other, and to make decisions based both on the overt language policies and on actual linguistic demands and practices in everyday life. Similar to the previous quote, an informant 
at the Police and Border Guard Board said the following as part of the discussion about the need to hire people who know Russian:

In our everyday work we are all based on what is easier. Well, we don't think about whether this is regulated by the law, rather we think that we as an institution need it and this is important for us.

According to the second informant at the same institution, the language requirements for both those working with the telephone information service and at the service centers include knowledge of three languages: Estonian, Russian and English. In her experience, this type of a trilingual profile is considered typical in Tallinn for the employees who are in direct contact with the public. The situation at the Tax and Customs Board is somewhat different, as they have experienced difficulties in finding employees for their service centre in Tallinn who can communicate with visitors in all three languages. Accommodating Russian at their service centres and the call centre is not a problem for this institution, as many of their employees belong to the older generation. The younger staff usually only command English as a foreign language and are not able to communicate with the Russian-speaking clientele.

It is important to emphasize that the data are not meant to illustrate the language requirements of Estonian state institutions in general, but only in that part of their activity which requires direct contact with the public. As was pointed out during the interview at the Unemployment Insurance Fund in connection to requirements for Russian in order to be hired in a state institution:

I wouldn't say that [Russian is necessary] in state institutions, rather in service departments. In state institutions French and English are used more than Russian. Russian is a big bonus, and in this area, in Tallinn, it is very difficult for people who can't make themselves understood in Russian, to work.

This valorization of Russian on the Estonian job market reflects the growing interest among the Estonian youth for the Russian language. After Estonia regained independence, interest for learning Russian was significantly reduced. Despite the fact that in the past two decades the study of Russian as L2 in Estonian schools has been widely replaced by English and other 'western' languages, there is now a notable interest among Estonians to acquire Russian. The importance of Russian in some areas of the working life has led to a 'comeback' situation, as 
'many young Estonians who graduate from secondary school with a rather poor command of Russian regret this later on, as they discover that a good command of Russian is an advantage in the labor market' (Siiner and Vihalemm 2011, 136). Russian is indeed an important resource in the service sector and tourism industry, and is valued as the language of transnational post-Soviet business networks (Pavlenko 2013). In Tallinn, Russian can be studied at various language schools and is experiencing an increase in the number of students (Veski 2013). According to a blog post published on April 2, 2014 on the website of Multilingua, one of the leading language schools in Tallinn, Russian is the second most popular language learned in their school after English. Their typical student of Russian is aged 26-35 years and takes the Russian course in order to be more competitive on the job market. A study based on the Estonian Labor Force Survey by Toomet (2011, quoted in Must 2013) showed that people who know Russian, receive an approximately $10 \%$ higher salary, and this corresponds to a $15-30 \%$ higher salary for those who speak English. Estonians, who work in the service industry, are still often required to know Russian (Skerrett 2011). For example, Swedbank, a leading bank in Estonia, has rejected applications for a position that requires communication with clients, which they received from Estonians who otherwise have perfect qualifications but lack Russian skills (Mellik 2010). When it comes to Estonians' own perception of languages that are important to know for personal development and career, the highest market value is reportedly attached to English (75\%), followed by Russian (47\%) and German (10\%) (Eurobarometer 2012). As for the L1 Russian speakers, it has been noted that for many of them, and especially in heterogeneous contexts like Tallinn, knowledge of the titular language - Estonian - is largely valued in instrumental terms, since it is associated with the possibility of progress and self-realization (Soler 2013). The Baltic Human Development Survey 2011 (quoted in Vihalemm et al. 2011) showed that knowledge of Estonian as second language is significantly tied to the perceived quality of life and social and economic positioning.

\section{Russian in Estonia's virtual public space}

In many areas of the world, older modes of communication and information transmission are gradually being replaced by what cyberspace and its associated technologies can offer. Therefore, when studying language use in state communication in a technologically progressive country, it becomes necessary not to focus exclusively on the physical public 


\section{DRAFT - Please do not cite}

space but also to shift our gaze towards the virtual public space. Estonia's advances in the field of digital technology have been very ambitious and remarkably successful. The country is often referred to as 'e-Estonia', and has received significant attention as being among the most technologically advanced countries in the world (see Jansen 2012 for a discussion of redesigning the image of post-Soviet Estonia). According to the Digital Economy and Society Index 2015 (published on the website of the European Commission), Estonia is currently the second best in Europe in the supply and use of digital public services. As stated on the website e-estonia.com, nearly $90 \%$ of Estonia's population hold an electronic ID card which can be used for digital signatures, electronic voting, declaring taxes online and checking your children's progress in e-school, to name a few.

Keeping in mind the growing digitization of the Estonian society, and the new communication methods between state institutions and the people, I would now like to focus on the presence of Russian on state websites, which is a previously little explored domain for an analysis of language management. Entering the website of a state institution can be considered like entering a 'virtual service center'. Various actions are possible on these websites, which are parallels of the physical service centers. For example, one can search for information, interact with the authorities, deliver the tax declaration, register as unemployed, apply for a residence permit, report change of address, and so on. When investigating the way space and prominence are allocated to specific languages on a website, we are dealing with the symbolic construction of the virtual public space. The emplacement of linguistic signs in this virtual space can be regarded as a representation of linguistic ideologies that 'overlay, more or less explicitly, all language use with value, be it social, cultural, political, moral, economic or otherwise' (Jaworski and Thurlow 2010, 11).

It is important to note that according to $\$ 31$ of the Public Information Act (2012), all government, state and municipal institutions in Estonia have an obligation to maintain a website. Hence all these institutions are at some point faced with the issue of which languages to display online, and what information to display in which language. No official language policy in Estonia specially regulates the use of other languages than Estonian in the virtual spaces. The rule of thumb for any institution or organization in Estonia is formulated in $\S 16(4)$ of the Language Act:

If the agencies, companies, non-profit associations and foundations and sole proprietors which are registered in Estonia have a web page in a foreign language which is directed to the public, 


\section{DRAFT - Please do not cite}

it shall include at least a summary in Estonian about its field of activity or the goods and services offered. (Official translation)

This corresponds well with the general principle of using Estonian and other languages in all areas of life, which, put in the words of Ilmar Tomusk, General Director of Estonia's Language Inspection, is the following: 'All other languages may be but Estonian must be' (video interview for Estonian Public Broadcasting, March 13, 2013). What this means in the case of the Estonian virtual public space, is that numerous other languages may be added to the website, as long as there is an Estonian summary of all the information offered. Which extra languages to add, is left to the individual organizations.

The most accessed e-service in Estonia, used by two thirds of all Internet users in the country, is the declaration of taxes (Statistics Estonia 2012), and according to the website visitestonia.com, $95 \%$ of people declare their income taxes online. I therefore now illustrate the use of Russian in the Estonian virtual public sector by giving an insight into the online communication strategies of the Estonian Tax and Customs Board. In recent years, the website of the Estonian Tax and Customs Board has become the main source of information, while the e-tax board has become the main service channel. As a result, visits to the service centers have decreased from around 400,000 clients in 2009 to 160,000 clients in 2013 (interview data).

According to my informant at the Tax and Customs Board, the institution is "playing on the borderline' between official regulations and real-life needs. As a state institution, they are required by the Language Act to use Estonian in official written communication and are not allowed to use Russian as much as they would prefer to. For example, in the e-tax board where declarations of income can be made online, the forms on the Russian version of the website can only be filled out in Estonian (the same applies to paper forms). Furthermore, an important communication strategy for the Tax and Customs Board is sending out 'mass emails', in order to disseminate information to a great number of private persons and almost eight thousand enterprises. In order to also reach those who have difficulties understanding Estonian, Russian and English translations were at one point added below the Estonian text in the e-mails. This was followed by several complaints from the Estonian users who accused the Tax and Customs Board of 'hurting national feelings' and violating the Language Act. Such reactions may be explained by the historical reasons that have led to Russian being perceived as offensive to the image of the new post-Soviet Estonia. However, when it comes to information on the website of the Tax and Customs Board being fully trilingual, no 
complaints about the Russian and English translation have been received. This could perhaps be explained by the fact that an e-mail arriving in one's Inbox can be perceived as an intrusion into one's personal space, while the action of looking up a website online is initiated by the user. In order to read the website in a different language, one needs to choose the language, and when one is not looking specifically for this information, the language choice could even stay unnoticed.

The use of Russian and English on state websites reflects the linguistic situation among employees at the service centers in Tallinn. What we see in the case of Estonia is that most state institutions (all in my study) in the country have a trilingual website in Estonian, Russian and English. An English version of state websites (not a full translation) is partially required due to EU regulations, and is also maintained as a source of information for foreign investors and new immigrants. Russian has a more everyday, functional value and is much more invested in, with almost all information and online actions available in Russian. While shorter translations and updates on the Russian domain can be done in-house, longer texts are sent to translation bureaus. This in turn means allocating funds to translation by the state institutions in order to maximize their ability to reach the whole population. One might argue that such an investment becomes even more vital when the state not only uses a foreign language for information distribution but also requires an action from the people, as is the case with the tax authorities. Finally, it is important to keep in mind that translation costs can be brought down drastically in the virtual space, compared to the price of producing brochures, forms and signage for the service centers, or employing workers with specific language skills. This makes a well-functioning multilingual website an essential communication strategy and important asset for state institutions. It is noteworthy that while state websites provide close to full information in Russian, the language is significantly less visible in the physical landscapes of the client service centers. Such a tendency can be seen as a concretization of Russian's subaltern status with regard to Estonian on the official level and illustrates the role of the written language in physical public spaces as an index of Estonian national identity (see for example Shohamy and Gorter 2009). Further research is needed to investigate in more detail why there is such a gap in the visibility of Russian in the physical and virtual public spaces.

\section{Conclusion}




\section{DRAFT - Please do not cite}

From the discussed above, we can see that the central state institutions in Estonia have the linguistic capacity to communicate with the Russian-speaking population to a large degree in Russian, both online and at their service centers. In this way, both the physical and virtual public spaces of officially monolingual Estonia are not that monolingual at all, and Russian speakers have the possibility to communicate with the Estonian state in their mother tongue. Of course, it is important to emphasize that the conclusions in this article about language use in the physical public space are based on data from Tallinn, which is more or less bilingual. While a similar situation may indeed be a reality in the northeastern part of Estonia with an even larger Russian-speaking part of the population (as was also mentioned by some of the interviewees), the results do not automatically apply to the rest of the country.

It is first and foremost in the service and communication oriented part of Estonia's public sector where we witness the commodification of Russian. People who work at the service centers are expected to know Russian, which in this context has more value than English. In many areas of the social life, and especially in Tallinn, a shift seems to have occurred from orienting to Russian as 'a problem' towards seeing it as 'a resource' (Ruíz 1984), a consequence of the repositioning of language in the new economy. We are here indeed witnessing a shifting political and economic reality where language is understood less as an 'essential element of identity, and more as a technical skill' (Heller 2012, 29). Moreover, it is Estonian speakers who are perpetuating this shift as they are learning Russian at language courses. It is important to note that for the state institutions in Estonia, Russian is an add-on, being only profitable when it is used in addition to the titular language. It is secondary both on state websites and as part of the linguistic resources of the employees at the service centers (followed by English in both cases). When it comes to the websites of state institutions in Estonia, we see that the institutions do enforce laws that give priority to the Estonian language in the virtual space; however, trilingual state websites in Estonian, Russian and English seem to be the unwritten norm. This is another example of the way state institutions invest in Russian, this time through translation.

In this article I have sought to illustrate a co-existence of conceptions of language as an official ideology and of language as a resource, a skill in regard to Russian in Estonia. There are asymmetrical relations of power in Estonia based on language skills, but in the service-based economy this seems to go both ways. On the one hand, knowledge of Estonian gives Russian speakers the ability to function as legitimate members of the society. On the other hand, knowledge of Russian in certain areas of the country, and in my study in Tallinn, provides Estonian speakers an access to a broader range of employment possibilities. For 
Estonians, learning the Russian language gives them the potential of greater employability; it is an investment into what can become a profit. It is also an asset to state institutions allowing them to reach their goal of communicating with all their target groups, both in the physical world and online. The interview data presented in this article show that in Estonia, despite a Language Act with a monolingual focus, there is 'a fair amount of pragmatism in how society and the administration function in practice' (Lagerspetz 2014, 15). Pragmatism is certainly not a neutral ideology either, and in the case of Estonian state institutions, it seems to favor the notion of a multilingual reality. So, whereas Russian is not specifically mentioned in the overt laws, it is de facto widely present in the country's public sector. In this way, public communication strategies in the Estonian state institutions featured in this article are more informed by an institutionally perceived need for Russian aiming at serving the Russianspeaking population, than by the overt language laws and monolingual ideology.

\section{Acknowledgements}

This work was partly supported by the Research Council of Norway through its Centres of Excellence funding scheme, project number 223265.

\section{References}

Blommaert, J., H. Kelly-Holmes, P. Lane, S. Leppänen, M. Moriarty, S. Pietikäinen, and A. Piirainen-Marsh. 2009. 'Media, Multilingualism and Language Policing.' Language Policy 8: 203-207.

Brubaker, R. 2011. 'Nationalizing states revisited: projects and processes of nationalization in post-Soviet states.' Ethnic and Racial Studies 34 (11): 1785-1814.

Bourdieu, P. 1991. Language and Symbolic Power. Cambridge: Harvard University Press.

Duchêne, A., and M. Heller, eds. 2012. Language in Late Capitalism: Pride and Profit. New York: Routledge.

Eesti Entsüklopeedia. 2012. Rahvuskoosseis Eestis [Ethnic composition of Estonia].

Ehala, M. and A. Zabrodskaja. 2014. 'Ethnolinguistic vitality and acculturation orientation of Russian speakers in Estonia.' In The Russian Language Outside the Nation, edited by Lara Ryazanova-Clarke, 166-188. Edinburgh: Edinburgh University Press.

Eurobarometer. 2012. Europeans and their Languages. Special Eurobarometer Report 386. Brussels: European Commission.

Gal, S. 1989. 'Language and Political Economy.' Annual Review of Anthropology 18: 345 367. 
Heller, M. 2010. 'The Commodification of Language.' Annual Review of Anthropology 39: 101-114.

Heller, M. 2012. 'Re-thinking Sociolinguistic Ethnography.' In Multilingualism, Discourse and Ethnography, edited by M. Martin-Jones and S. Gardner, 24-33. London: Routledge.

Hine, C. 2000. Virtual Ethnography. London: Sage.

Irvine, J. T. and S. Gal. 2000. 'Language Ideology and Linguistic Differentiation.' In Regimes of Language, edited by P. Kroskrity, 35-83. Santa Fe: School of American Research Press.

Jansen, S. C. 2012. 'Welcome to E-stonia, 2001-2018.' In Branding Post-Communist Nations, edited by N. Kaneva, 79-98. New York: Routledge.

Jaworski, A. and C. Thurlow. 2010. 'Introducing Semiotic Landscapes.' In Semiotic Landscapes: Language, Image, Space, edited by A. Jaworski and C. Thurlow, 1-40. London: Continuum.

Kelly-Holmes, H. 2015. 'Analyzing Language Policies in New Media.' In Research Methods in Language Policy and Planning: A Practical Guide, edited by F. M. Hult and D. C. Johnson, 130-139. Hoboken, NJ: John Wiley \& Sons.

Kivirähk, J. 2014. Integrating Estonia's Russian-Speaking Population: Findings of National Defense Opinion Surveys. Tallinn: International Centre for Defense and Security.

Lagerspetz, M. 2014. 'Cultural Autonomy of National Minorities in Estonia: The Erosion of a Promise.' Journal of Baltic Studies 45 (4): 457-475.

Language Act. 2011. At www.riigiteataja.ee/en/eli/506112013016/. Accessed 28.08.2015.

Lauristin, M. 2011. 'Lõimumisprotsessi tulemuslikkus ja sihtrühmad: klasteranalüüs.' [The performance of the integration process and the different target groups: cluster analysis]. Estonian Integration Monitoring 2011. Tallinn: Ministry of Culture.

Lauristin, M., and M. Heidmets, eds. 2002. The Challenge of the Russian Minority: Emerging Multicultural Democracy in Estonia. Tartu: Tartu University Press.

Mellik, J. 2010. Eesti noorte vene keele oskus jätab soovida [Russian skills of the Estonian youth leave to be desired]. Postimees, July 26.

Ministry of Culture. 2014. Lõimuv Eesti 2020 [The Strategy of Integration and Social Cohesion in Estonia 2020].

Must, M. 2013. Eesti noored jäävad haritud venelastele tööjouturul alla [Estonian youth loses to educated Russians on the labor market]. Delfi, January 16.

Nekvapil, J. 2006. 'From Language Planning to Language Management.' Sociolinguistica 20: 92-104.

Ozolins, U. 2003. 'The Impact of European Accession upon Language Policy in the Baltic States.' Language Policy 2: 217-238.

Pavlenko, A. 2008. 'Multilingualism in Post-Soviet Countries: Language Revival, Language Removal, and Sociolinguistic Theory.' International Journal of Bilingual Education and Bilingualism 11 (3-4): 275-314.

Pavlenko, A. 2013. 'Multilingualism in Post-Soviet Successor States.' Language and Linguistics Compass 7 (4): 262-271.

Public Information Act. 2012. At https://www.riigiteataja.ee/akt/119122012005. Accessed 28.08.2015.

Rannut, M. 2008. 'Estonianization Efforts Post-Independence.' International Journal of Bilingual Education and Bilingualism 11(3-4): 423-439.

Ruíz, R. 1984. 'Orientations in Language Planning.' NABE Journal 8 (2): 15-34.

Sarangi, S., and C. Roberts, C., eds. 1999. Talk, Work and Institutional Order: Discourse in Medical, Mediation and Management Settings. Berlin: Walter de Gruyter. 
Schiffman, H. F. 1995. Linguistic Culture and Language Policy. New York: Routledge.

Shohamy, E. G. 2006. Language Policy: Hidden Agendas and New Approaches. New York: Routledge.

Shohamy, E., and D. Gorter, eds. 2009. Linguistic Landscape: Expanding the Scenery. New York: Routledge.

Siiner, M. 2006. 'Planning Language Practice: A Sociolinguistic Analysis of Language Policy in Post-Communist Estonia.' Language Policy 5 (2): 161-186.

Siiner, M., and T. Vihalemm. 2011. Individual multilingualism in the Baltic states within the European context. In Estonian Human Development Report 2010/2011. Baltic Way(s) of Human Development: Twenty Years On, edited by T. Vihalemm, 135-137. Tallinn: Eesti Koostöö Kogu.

Skerrett, D. M. 2011. 'Languages and Lives through a Critical Eye: the Case of Estonia.' Critical Inquiry in Language Studies 8 (3): 236-260.

Soler, J. 2013. 'The Anonymity of Catalan and the Authenticity of Estonian: Two Paths for the Development of Medium-sized Languages.' International Journal of Bilingual Education and Bilingualism 16 (2): 153-163.

Spolsky, B. 2004. Language Policy. New York: Cambridge University Press.

Tallinn City Government. 2014. Statistical Yearbook of Tallinn 2014. Tallinn City Office.

Toomet, O. 2011. 'Learn English, Not the Local Language! Ethnic Russians in the Baltic States.' American Economic Review 101 (3): 526-531.

Veski, R. 2013. Dimitri Mironov: eestlaste huvi vene keele vastu kasvab pidevalt [Dimitri Mironov: Estonians' interest for the Russian language is steadily growing]. Postimees, November 11.

Vihalemm, T., M. Siiner, and A. Masso. 2011. 'Introduction: Language Skills as a Factor in Human Development.' In Estonian Human Development Report 2010/2011. Baltic Way(s) of Human Development: Twenty Years on, edited by T. Vihalemm, 116-118. Tallinn: Eesti Koostöö Kogu. 